\title{
EFEKTIFITAS PENYEBARAN INFORMASI COVID-19 MELALUI MEDIA TWITTER KEMENTRIAN KESEHATAN REPUBLIK INDONESIA DAN BADAN NASIONAL PENANGGULANGAN BENCANA
}

\author{
Anang Setiawan \\ Herdin Arie Saputra \\ Muhammad Eko Atmojo \\ Magister Ilmu Pemerintahan, Universitas Muhammadiyah Yogyakarta
}

\begin{abstract}
Abstrak
Teknologi informasi yang ada harus dimanfaatkan oleh pemerintah dalam menjalin komunikasi maupun transparansi data. Kedua hal itu menjadi sangat penting disaat pandemi seperti sekarang ini. Mengingat platform yang bisa digunakan untuk komunikasi maupun penyajian data sangat beragam, sehingga tidak ada alasan untuk tidak terbuka terhadap masyarakat terutama dalam hal penyajian data covid19. Riset ini menggunakan metode kualitatif deskriptif dengan melakukan penelusuran pada akun twitter Kementerian Kesehatan RI dan Badan Nasional Penanganan Bencara RI selama periode 3 Maret 2020 hingga 31 Mei 2020. Kementerian Kesehatan Republik Indonesia telah melakukan himbauan untuk mengajak masyarakat agar tetap waspada pada covid-19. Interaksi twitter Badan Nasional Penanggulangan Bencana Republik Indonesia diawal masa pandemic yaitu pada bulan Maret tahun 2020 mempunyai nilai interaksi tweet sebesar $11.36 \%$, di bulan April sebesar 18.72\%, dan ada bulan Mei sebesar $17.69 \%$ yang memberikan informasi terkait dengan pandemi covid-19, berbagai aspek di situasi pandemi seperti penanggulangan, pencegahan, hingga informasi terkonfirmasinya covid-19 di Indonesia, terkomunikasikan.
\end{abstract}

Kata Kunci: Efektifitas, Informasi Covid-19, Kemenkes, BNPB.

\section{PENDAHULUAN}

Era industry 4.0 merupakan salah satu era keterbukaan informasi publik, maka dari itu banyak sekali media yang bisa digunakan untuk mendukung pola komunikasi maupun aktivitas pemerintah. Dengan adanya keterbukaan informasi ini sangat mempermudah masyarakat untuk melakukan komunikasi maupun kontrol terhadap kegiatan yang dilakukan oleh pemerintah. Hal tersebut merupakan salah satu bentuk kemudahan akses keterbukaan informasi publik yang didukung dengan informasi teknologi. 
Adanya informasi teknologi ini sangat membantu masyarakat dalam melakukan komunikasi, salah satunya melalui media sosial. Masyarakat Indonesia mempunyai pola komunikasi sangat intens melalui media sosial. Hal ini dapat dilihat dari pernyataan Nasrullah dalam (Setiadi, n.d.) bahwa pengguna internet dan media sosial di Indonesia sangat tinggi. Tingginya penggunaan internet ini menunjukkan bahwa semakin banyak masyarakat Indonesia yang produktif berkomunikasi melalui media sosial. Yang paling banyak platform media sosial yang digunakan di Indonesia adalah facebook dan twitter. Berdasarkan pernyataan Kementerian Komunikasi dan Informatika (dikutip dalam Munandar \& Suherman, 2016) bahwa terdapat 63 juta orang Indonesia yang menggunakan internet, serta 95 persen di antaranya menggunakan situs jejaring sosial. Selain itu (Munandar \& Suherman, 2016) juga menyatakan pengguna facebook di Indonesia terdapat 65 juta pengguna aktif, sedangkan untuk pengguna twitter menempati urutan ke-5 dunia dengan jumlah pengguna aktif sebanyak 19,5 juta. Dengan banyaknya pengguna media sosial ini memunculkan spekulasi bahwa masyarakat Indonesia pada saat ini banyak yang memanfaatkan maupun mengoptimalkan media sosial sebagai media komunikasi.

Memang dengan adanya media sosial pola komunikasi menjadi sangat mudah dan terbuka, karena pola yang ditawarkan dalam media sosial cenderung lebih terbuka untuk umum. Berdasarkan pernyataan dari Susanto (2017) bahwa pola penyebaran pesan yang cenderung bebas memiliki maksud untuk segera diketahui oleh khalayak umum. Hal inilah yang bisa menjadi problem terutama dalam hal keakuratan atau kevalidan berita. Dengan banyaknya pengguna media sosial dan semakin luasnya penyebaran berita mengakibatkan pola komunikasi menjadi tidak terkontrol. Hal semacam ini juga berlaku bagi instansi pemerintahan, mengingat pada saat ini pemerintah di minta untuk menyajikan berita maupun data secara cepat dan tepat. Maka salah satu media yang bisa digunakan oleh instansi pemerintah adalah media sosial.

Salah satu media sosial yang sering digunakan oleh pemerintah adalah website, twitter, YouTube dan Instagram. Dengan banyaknya media sosial yang bisa digunakan menjadikan interaktif penyajian berita maupun data semakin kompleks, 
sehingga perlu ketelitian dan kehati-hatian dalam penyajian data. Penggunaan media sosial yang banyak ini menjadi salah satu model komunikasi bagi pemerintah dalam mewujudkan good governance khususnya transparansi. Mengingat dalam konsep good governance pemerintah dituntut untuk bisa transparan dan terbuka kepada masyarakat. Oleh karena tu, penggunaan teknologi informasi harus dimaksimalkan dengan baik, sehingga bisa mendukung jalannya roda pemerintahan serta mewujudkan tata kelola pemerintahan yang baik atau good governance.

Pola komunikasi merupakan modal utama untuk menjalankan roda pemerintahan, salah satunya pola atau model komunikasi antarlembaga negara atau instansi pemerintah. Hal ini sangat penting karena instansi pemerintah mempunyai peran yang sangat vital dalam tata kelola pemerintahan yang baik. Sehingga komunikasi harus dilakukan secara intens serta dilakukan dengan baik. Jika kita lihat mengenai pola komunikasi di masa pandemi ini ada beberapa komunikasi yang belum berjalan dengan baik antar instansi pemerintah. Seperti pernyataan dari Kepala Pusat Data Informasi dan Komunikasi Kebencanaan BNPB yang menyatakan bahwa data mengenai kasus positif covid-19 yang selama ini disajikan oleh Pemerintah Pusat belum sinkron dengan Pemerintah Daerah (Flo, 2020).

Teknologi informasi yang ada harus dimanfaatkan oleh pemerintah dalam menjalin komunikasi maupun transparansi data. Hal itu menjadi penting disaat pandemi seperti sekarang ini. Mengingat platform yang bisa digunakan untuk komunikasi maupun penyajian data sangat beragam, sehingga tidak ada alasan untuk tidak terbuka terhadap masyarakat terutama dalam hal penyajian data covid19. Jika dilihat di awal pandemi memang ada perbedaan antarlembaga atau intansi, hal ini juga diakui oleh BNPB, selain itu Kementerian Kesehatan yang sebagai leading sector dalam urusan pandemi ini juga mengalami ketidakterbukaan atau transparansi data. Hal tersebut diungkapkan oleh BPNP bahwa Kementerian Kesehatan tidak terbuka dalam menyampaikan data kasus covid-19, selain itu BNPB juga tidak bisa mengkases data secara menyeluruh (Widhana, 2020).

Minimnya komunikasi serta tidak adanya keterbukaan tersebut membuat masyarakat semakin bingung dalam menerima data covid-19, sehingga muncul ketidakpercayaan dari masyarakat terhadap pemerintah karena pemerintah 
dianggap tidak solid dalam menangani kasus covid-19 di Indonesia. Oleh karena itu penulis ingin mendalami penelitian tentang efektivitas penyebaran nformasi covid-19 melalui akun twitter BNPN dan Kementerian Kesehatan.

Dalam penelitian ini metode yang digunakan adalah metode kualitatif deskriptif dengan melakukan penelusuran pada akun twitter Kementerian Kesehatan RI dan Badan Nasional Penanganan Bencara RI selama periode 3 Maret 2020 hingga 31 Mei 2020. Teknik dalam proses analisis melewati lima tahapan: Studi literatur, menemukan model dalam penggunaan media sosial untuk berkomunikasi, mengumpulkan data dari twitter, analisis Nvivo 12 Plus, menarik kesimpulan dari model penggunaan media social. Setelah dianalisis dikelompokkan menurut kajian dan tujuan penelitian yaitu, (1). Pola interaksi yang terjadi pada kedua akun twitter, dan (2). Penyebaran informasi yang dilakukan oleh pemerintah.

Twitter Kementerian Kesehatan Republik Indonesia, dan Badan Nasional Penanggulangan Bencana RI. Indonesia melalui tahap Ncapture Nvivo 12 Plus, selanjutnya analisis melalui software Nvivo 12 Plus yang diperuntukan untuk menganalisis data kualitatif berbasis internet, pengkodean data, menguji validitas dan reliabilitas, serta visualisasi hasil analisis data.

\section{PEMBAHASAN}

\section{A. Jumlah Tweet Kementerian Kesehatan Republik Indonesia dan Badan Nasional Penanggulangan Bencana (BNPB)}

Pola interaksi yang signifikan dalam media social platform twitter Kementerian Kesehatan Republik Indonesia dan Badan Nasional Penanggulangan Bencana pada saat pandemic covid-19, hal ini berdasarkan dengan arahan dari Presiden Republik Indonesia yang selalu memberikan informasi berlandaskan datadata yang akurat. Di bawah ini jumlah tweet berdasarkan akun twitter Kementerian Kesehatan Republik Indonesia dan Badan Nasional Penanggulangan Bencana: 


\section{Gambar 1}

\section{Jumlah Tweet Kementerian Kesehatan Republik Indonesia}

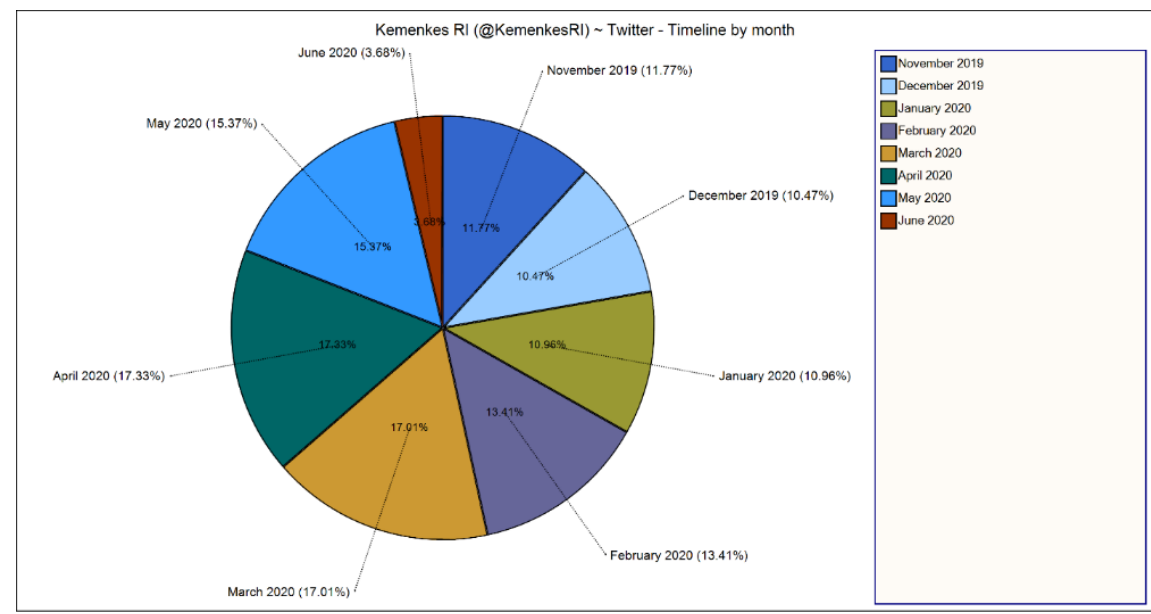

Berdasarkan gambar di atas menunjukkan bahwa jumlah tweet interaksi yang dilakukan oleh Kementerian Kesehatan Republik Indonesia pada saat pandemi covid-19 masuk ke Indonesia bulan Maret tahun 2020 sebesar 17.01\%, pada bulan April sebesar $17.33 \%$, dan pada bulan Mei sebesar $15.37 \%$ yang berisi informasi terkait dengan protokol kesehatan jika mengalami gejala covid-19, situasi terkini perkembangan covid-19 di Indonesia, memberikan informasi terkait pasien covid19, serta ajakan kepada masyarakat untuk tetap berada di rumah untuk memutus rantai penularan dan penyebaran covid-19 salah satunya dengan membatasi aktivitas di luar rumah, terutama jika mengalami gejala-gejala demam, batuk, dan sesak nafas. Selanjutnya memberikan motivasi kepada para perawat karena sudah menjadi garda terdepan pada saat pandemi. Jika dilihat dengan rentang waktu 3 bulan awal masa pandemi jumlah interaksi maupun tweet sangat signifikan saling berhubungan dengan beberapa akun lainnya, dan selalu memberikan informasi mengenai corona virus yang terjadi di Indonesia.

Kementerian Kesehatan Republik Indonesia telah melakukan segala aktivitas berdasarkan himbauan untuk mengajak masyarakat agar tetap waspada pada covid-19. Akan tetapi usaha interaksi di platform twitter tidak menurun seiring dengan semakin melonjaknya covid-19 ini. Di bawah ini terekam beberapa akun twitter di sektor lainnya yang dilakukan oleh akun twitter Badan Nasional Penanggulangan Bencana Republik Indonesia: 
Gambar 2

Jumlah Tweet Badan Nasional Penanggulangan Bencana (BNPB)

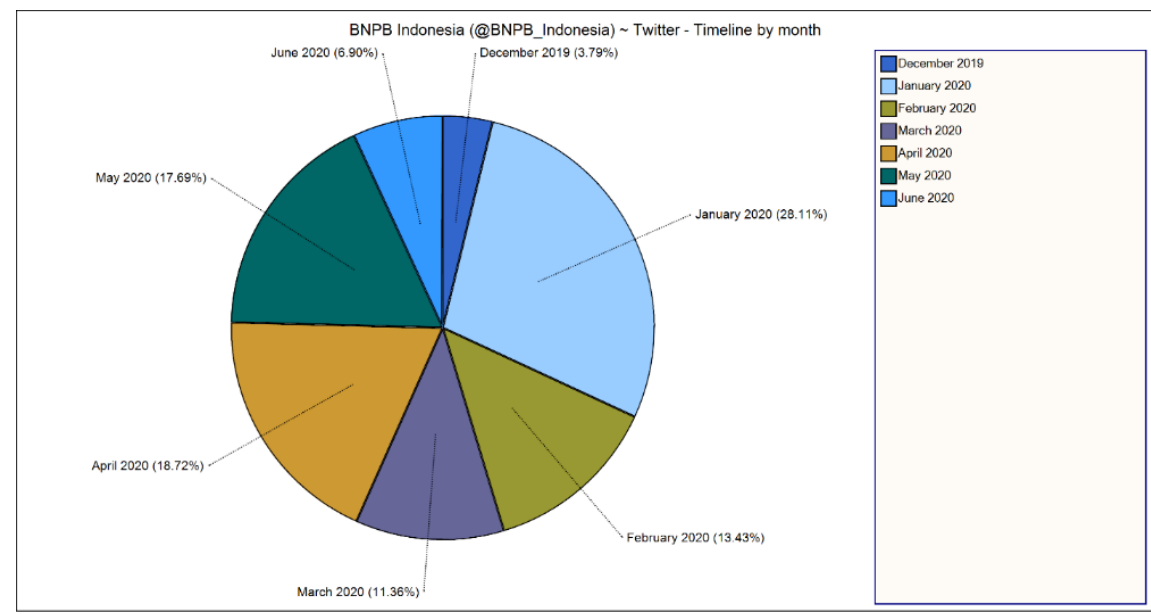

Berdasarkan gambar di atas pada platform twitter Badan Nasional Penanggulangan Bencana Republik Indonesia diawal masa pandemi yaitu pada bulan Maret tahun 2020 mempunyai nilai interaksi tweet sebesar 11.36\%, di bulan April sebesar $18.72 \%$, dan ada bulan Mei sebesar $17.69 \%$ yang memberikan informasi terkait dengan pandemi covid-19, berbagai aspek di situasi pandemi seperti penanggulangan, pencegahan, hingga informasi terkonfirmasinya covid-19 di Indonesia. Di sisi lain, Badan Nasional Penanggulangan Bencana (BNPB) juga bekerja untuk penanggulangan bencana lainnya, seperti banjir, gempa, dan longsor. Hal tersebut membuat Badan Nasional Penanggulangan Bencana harus bekerja keras, bukan hanya fokus ke pandemi covid-19, tetapi terpecah dalam beberapa hal yang harus di ambil alih oleh BNPB. Oleh karena itu, pemerintah harus bisa memisahkan atau membuat satuan khusus untuk bisa memblokir serta mencegah corona virus dengan skala yang lebih struktur dan massif.

Pada dasarnya akun twitter Kementerian Kesehatan Republik Indonesia dan Badan Nasional Penanggulangan Bencana Republik Indonesia di bulan Maret hingga Mei 2020 sangat aktif dalam memberikan informasi mengenai pandemi, sedangkan hal yang berbeda hanya di akun Badan Nasional Penanggulangan Bencana Republik Indonesia (BNPB) yang secara struktur harus bekerja lebih keras karena terjadinya beberapa bencana (longsor, banjir, dan gempa) di wilayahwilayah yang ada di Indonesia. 


\section{B. Indonesia dan Badan Nasional Penanggulangan Bencana}

Pola interaksi berdasarkan mentions sangat mempengaruhi jalannya aktivitas informasi di media sosial berbagai platform, ini dikarenakan saling mendukung serta menguatkan isi dari sebuah informasi dan relasi hubungan antara lembaga yang ada di suatu negara terkait beberapa tema yang sama. Pada platform twitter mentions sangat berguna untuk mendukung sebuah informasi dengan tema yang sama dan relevan sehingga dapat dibahas lebih lanjut, dan juga sangat dibutuhkan dari berbagai akun twitter lainnya berdasarkan followers akun-akun yang sering memberikan mentions jika ada informasi yang penting.

\section{Gambar 3}

\section{Interaksi Twitter Kemenkes RI}

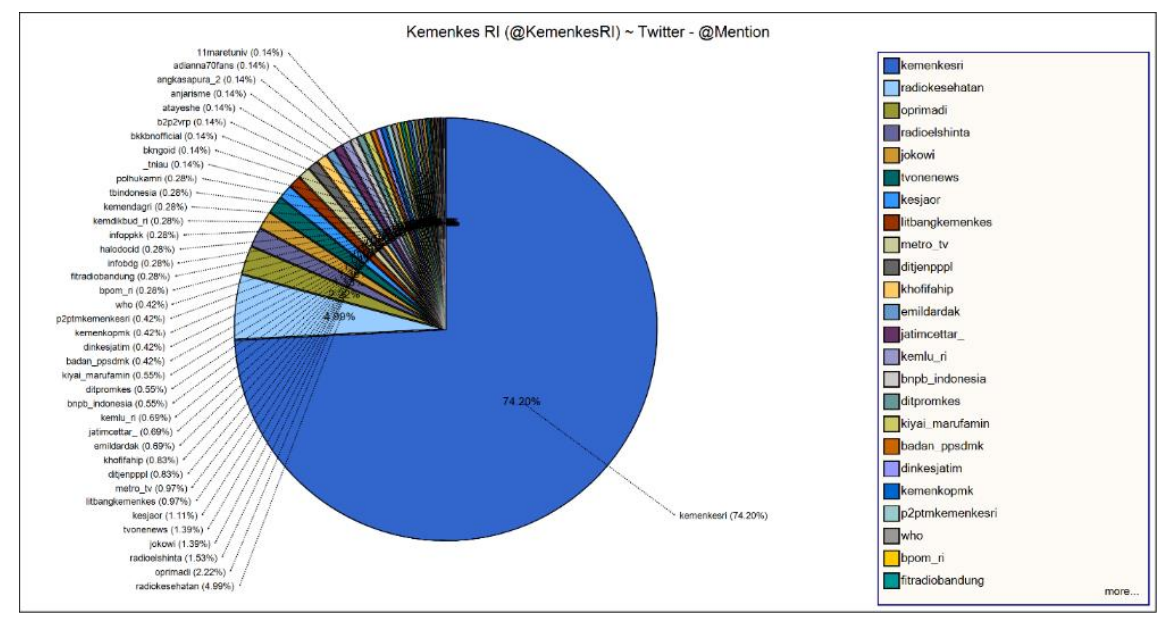




\section{Gambar 4}

\section{Interaksi Twitter Badan Nasional Penanggulangan Bencana}

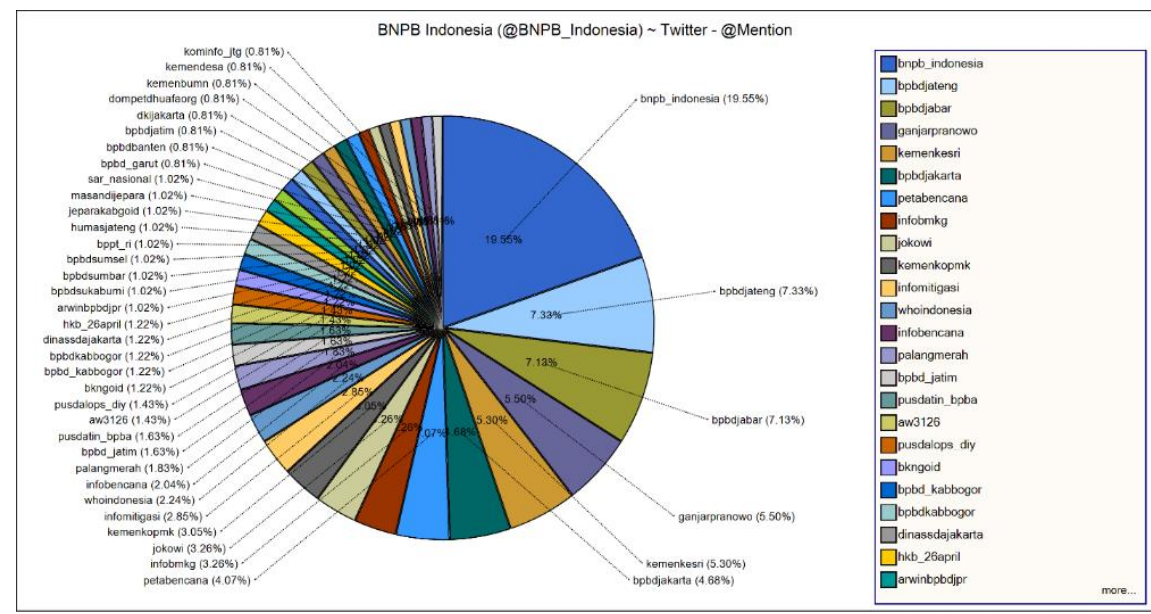

Berdasarkan gambar di atas menunjukkan bahwa interaksi berdasarkan mentions pada akun twitter Kementerian Kesehatan Republik Indonesia saling berhubungan dengan beberapa akun twitter lainnya serta menunjukkan seberapa besar nilai interaksi yang dilakukan, @radiokesehatan mempunyai interaksi dengan akun KemenkesRI dengan besar nilai interaksi yaitu $4.99 \%$ yang menyatakan terkait informasi seputar corona virus (covid-19), disusul oleh akun @oprimadi sebagai Sekretaris Jenderal Kementerian Kesehatan Republik Indonesia dengan nilai interaksi sebesar $2.22 \%$ yang memberikan informasi serta menjawab semua pertanyaan terkait dengan corona virus di beberapa stasiun televisi dan radio di beberapa daerah, selanjutnya akun @ radioelshinta dengan besaran interaksi yaitu $1.53 \%$ yang interaksinya menyediakan fasilitas serta wadah untuk memberikan informasi kepada masyarakat, sedangkan untuk interkasi akun twitter Badan Nasional Penanggulangan Bencana (BPNB) dengan beberapa akun twitter seperti @bpbdjateng mendapatkan nilai interaksi 7.33\% yang memberikan informasi interaksi berupa bencana alam (longsor dan banjir) dikarenakan hujan yang begitu deras yang dialami di wilayah jawa tengah, selanjutnya terkait dalam penaggulangan coronavirus (covid-19) hanya beberapa tweet yang memberikan informasi dalam penanggulangan pandemic tersebut, tidak intens dalam memberikan informasi tentang covid-19. Disusul oleh akun@bpbdjabar dengan nilai interaksi $7.13 \%$ yang memberikan informasi berupa bencana alam (banjir, 
gempa dan longsor) yang dialami di wilayah jawa barat dalam situasi pandemic, akun ini juga hanya me-retweet beberapa informasi tentang penanggulangan covid19.

\section{Berdasarkan Retweet pada Twitter Kementerian Kesehatan Republik Indonesia dan Badan Nasional Penanggulangan Bencana}

Interaksi berdasarkan retweet salah satu untuk mendukung informasi yang di publikasikan oleh salah satu akun twitter yang menjadi acuan untuk segala aktivitas yang ada dalam media sosial maupun dalam perilaku, sebagai bentuk motivasi yang didukung oleh akun lainnya pada tema yang sama dan relevan.

\section{Gambar 5}

\section{Tipe Retweet Kemenkes RI}

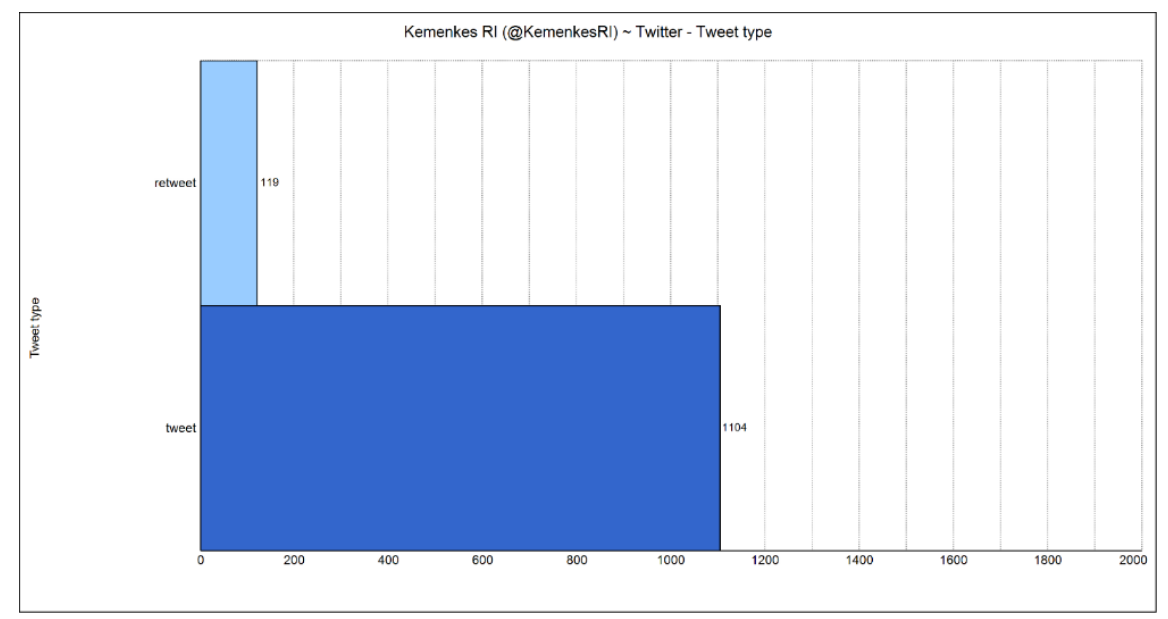




\section{Gambar 6}

Tipe Retweet Badan Nasional Penanggulangan Bencana

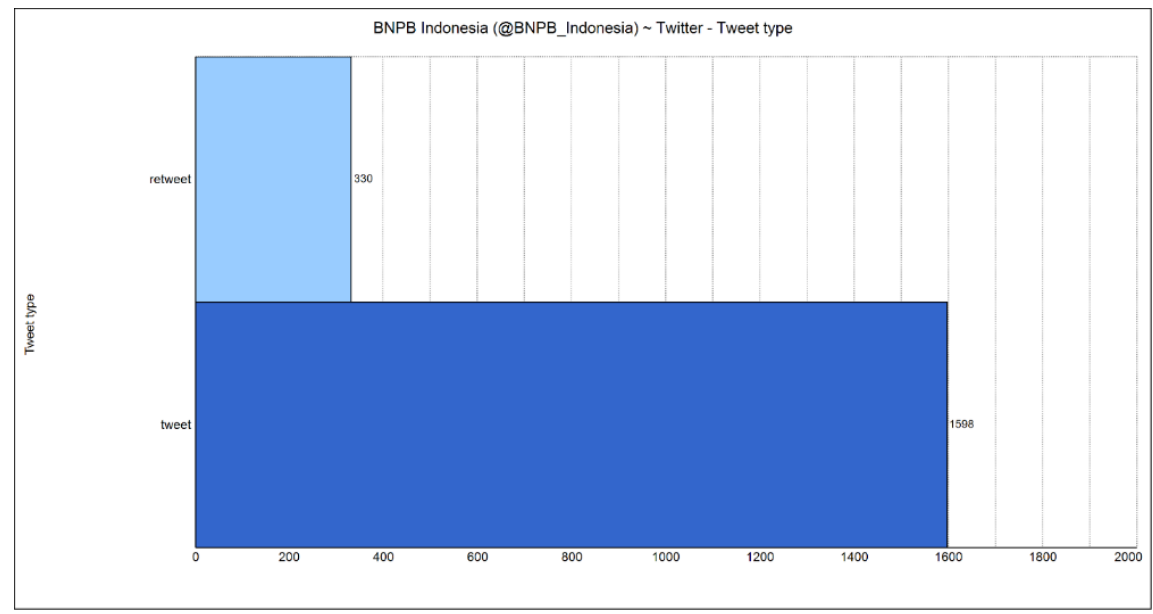

Berdasarkan gambar di atas menunjukkan bahwa tipe tweet yang dilakukan oleh akun twitter @kemenkesRI dominan ke tweet daripada retweet, nilai tweet dari KemenkesRI sebesar 1104, sedangkan retweet yang dilakukan sebesar 119, adapun isi retweet dari KemenkesRI yaitu berupa informasi pengenalan coronavirus hingga pencegahan, dan me-retweet informasi hoax yang telah beredar di tengah-tengah masyarakat dalam bentuk voice note. Sedangkan untuk akun twitter Badan Nasional Penanggulangan Bencana dengan nilai tweet sebesar 1598, sedangkan untuk retweet sebesar 330, adapun isi dari retweet tersebut mengenai informasi tentang bencana alam (gempa, longsor, dan banjir) yang dialami di beberapa wilayah, selanjutnya tidak lepas dari informasi pandemi covid-19 serta bantuan sosial (bansos). Dalam akun tweet Badan Nasional Penanggulangan Bencana banyak informasi mengenai bencana alam serta pandemi covid-19, ini membuktikan bahwa BNPB selalu memberikan informasi mengenai bencana yang dialami di wilayah manapun terlepas dari bencana pandemi covid-19. Tweet Badan Nasional Penanggulangan Bencana juga mempunyai tweet lebih banyak daripada akun KemenkesRI yang setiap saat memberikan informasi yang relevan dalam situasi apapun. 


\section{Word Frequency pada Twitter Kementerian Kesehatan Republik Indonesia dan Badan Nasional Penanggulangan Bencana}

Dalam pola interaksi akun twitter Kementerian Kesehatan Republik Indonesia dan Badan Nasional Penanggulangan Bencana Republik Indonesia (BNPB) berdasarkan kosa kata yang sering disebutkan dalam membahas wabah coronavirus (covid-19). Di bawah ini kosa kata (word frequency) pada awal masa pandemi yaitu di bulan Maret, April hingga Mei 2020:

\section{Gambar 7}

\section{Word Frequency Twitter Kemenkes RI}

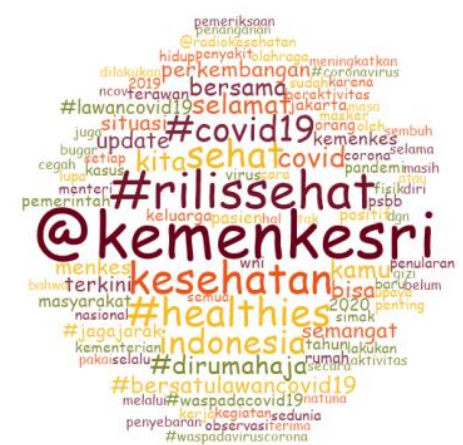

Berdasarkan gambar di atas menunjukkan bahwa ada beberapa kalimat yang sering disebutkan oleh KemenkesRI sebagai himbauan serta untuk memberikan motivasi kepada masyarakat Indonesia yaitu seperti rilissehat, healthies, kesehatan, bersama. Dalam hal ini Kemenkes masih mengajak atau memberikan motivasi untuk berkerja sama dalam menangani pandemic covid-19, terlihat jelas dari kalimat-kalimat yang sering digunakan dalam setiap memberikan informasi di tengah situasi pandemi. Pemerintah telah berupaya semaksimal mungkin tetapi masih saja kewalahan dalam mencegah serta memutus rantai covid-19, dapat ditemukan ajakan dari kalimat yang didapatkan yaitu \#bersatumelawancovid19. Selanjutnya tidak lepas dari perkembangan informasi yang didapatkan mengenai jumlah pasien yang terkonfirmasi covid-19 di Indonesia. 


\section{Gambar 8}

\section{Word Frequency Twitter Badan Nasional Penanggulangan Bencana (BNPB) \\ Word Frequency Twitter Badan Nasional Penanggulangan Bencana} (BNPB)

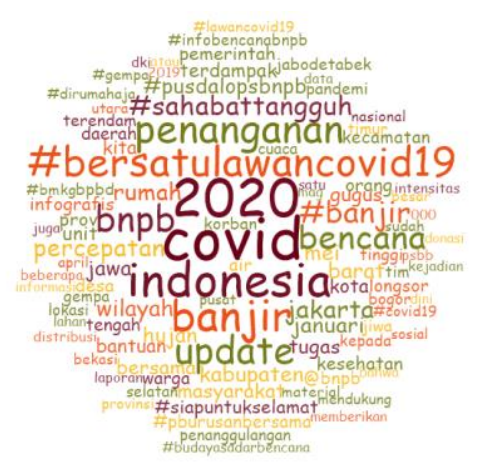

Berdasarkan gambar di atas yang didapatkan dari word frequency akun twitter Badan Nasional Penanggulangan Bencana (BNPB) menunjukkan bahwa kalimat yang sering digunakan dalam akun twitter BNPB yaitu covid, Indonesia, penanganan. Dalam hal ini jelas bagaimana BNPB memberikan ajakan dalam memerangi pandemi covid-19 dengan kalimat \#bersatumelawancovid19, dengan situasi saat ini akun twitter Kemenkes RI serta Badan Nasional Penanggulangan Bencana (BNPB) sama-sama mempunyai kalimat ajakan kepada masyarakat Indonesia dengan \#bersatumelawancovid19. Akan tetapi ada yang memberikan perbedaan dalam akun twitter BNPB yaitu selalu intens memberikan informasi mengenai bencana alam seperti banjir, longsor, dan gempa bumi. Badan Nasional Penanggulangan Bencana juga berfokus pada kota-kota besar dalam melihat skala bencana yang ada, seperti kalimat yang ditemukan dalam akun twitter yaitu Jakarta dan wilayah Jawa lainnya.

\section{E. Penyebaran informasi}

Komunikasi akun twitter@kemenkesRI dan @BNPB_Indonesia terhadap kebutuhan informasi pada masa pandemi covid-19 sangatlah penting bagi komunikan yakin akan mengalami kepuasan, mengalami reaksi yang menyenangkan, memperoleh reward (balasan positif) dan terhindar dari 
punishment (keadaan, kondisi yang tidak enak) dari komunikator, jika menerima atau menggunakan isi pesannya. Biasanya ketaatan atau ketundukan akan terjadi bila komunikan berhadapan dengan kekuasaan (power) yang dimiliki komunikator.

Komunikasi yang intensif juga dapat menangkal dari berita-berita hoax covid 19 yang dapat membuat kepanikan di masyarakat.

\section{Gambar 9}

Informasi Per-Minggu Kemenkes RI

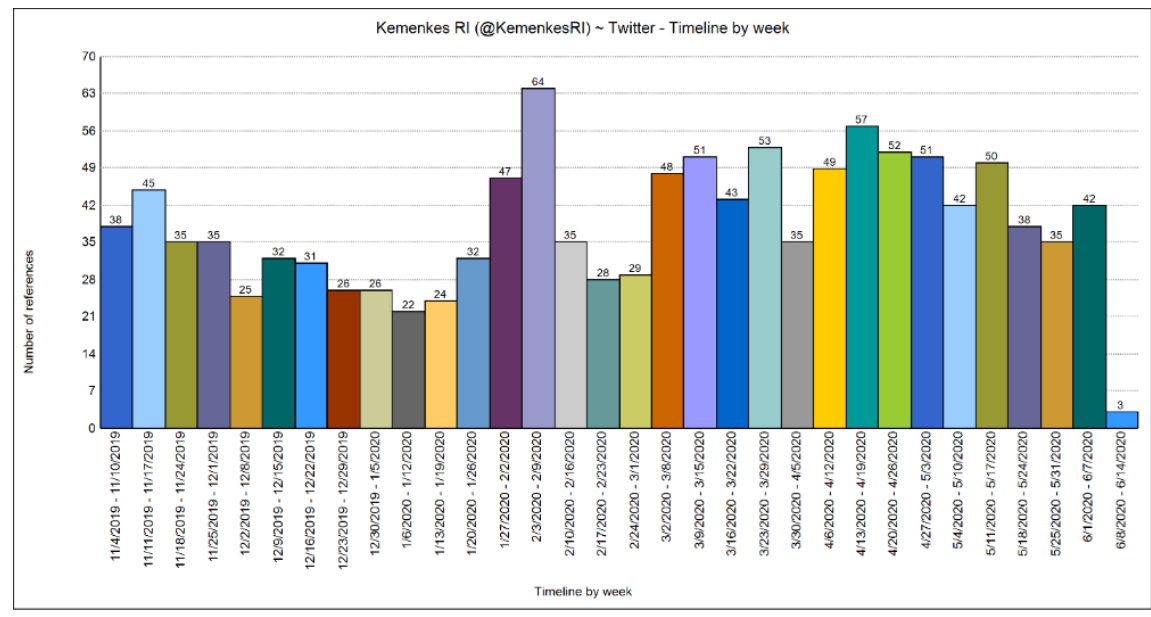

Pada gambar tersebut dijelaskan aktivitas tweet yang dilakukan oleh

Kementerian Kesehatan Republik Indonesia, pada minggu pertama bulan Maret tanggal 1 Maret hingga 8 Maret 2020 jumlah postingan kemenkes 48 tweet. Pada minggu kedua bulan Maret jumlah postingan Kemenkes 51 tweet, pada minggu ketiga bulan Maret jumlah postingan Kemenkes 43 tweet, pada minggu empat bulan Maret jumlah postingan Kemenkes 53 tweet, pada minggu kelima bulan Maret jumlah postingan Kemenkes 35 tweet, pada minggu pertama bulan April 2020 jumlah postingan Kemenkes 49 tweet. Pada minggu kedua bulan April jumlah postingan Kemenkes 57 tweet, pada minggu ketiga bulan April jumlah postingan Kemenkes 52 tweet, pada minggu empat bulan April jumlah postingan Kemenkes 51 tweet, memasuki minggu pertama bulan Mei 2020 jumlah postingan 42 tweet, minggu ketiga bulan Mei 2020 jumlah postingan 38 tweet, minggu empat bulan Mei 2020 jumlah postingan 35 tweet dan minggu kelima bulan Mei 2020 jumlah postingan 50 tweet. 
Informasi yang diberikan Kemenkes melalui tweet-nya adalah melaporkan kepada masyarakat jumlah pasien penderita covid 19 setiap harinya. Baik yang terkonfirmasi covid, negatif, positif ataupun yang meninggal. Hal ini dilakukan oleh Kemenkes untuk memberikan data yang valid kepada masyarakat agar tidak bingung dengan berapa pasien yang terkonfirmasi covid-19. Pemerintah juga memberikan himbauan kepada masyarakat terkait dengan pencegahan dan penanganan penyebaran covid-19 di Indonesia. Hal ini merupakan bentuk kepedulian pemerintah dalam mengedukasi masyarakat soal pentingnya pencegahan covid-19. Pemerintah juga memberikan arahan kepada masyarakat dalam bentuk bagaimana alur deteksi covid-19 yang dapat dilakukan oleh masyarakat secara mandiri. Pada tweet juga dijelaskan apa saja kebijakan pemerintah pusat dalam penanganan covid-19 dan perkembangan daerah yang mengajukan PSBB juga masuk dalam tweet ini. Dalam menandai aktivitas tweetnya Kemenkes menggunakan \#WaspadaCOVID19 dan \#BersatuLawanCovid19 agar masyarakat dapat mudah menemukan postingan Kemenkes dan agar pesan yang disampaikan dapat diterima oleh masyarakat luas. Informasi yang diberikan oleh Kementerian Kesehatan sudah cukup efektif jika dilihat dari factor tersebut di atas. Kesesuaian data antara pemerintah pusat dan daerah menjadi permasalahan yang cukup rumit, karena adanya perbedaan data yang ditampilkan oleh pemerintah pusat dan pemerintah daerah, Jika dilihat dari akun twitter pemerintah yang lainnya yaitu Badan Penanggulan Bencana Daerah Republik Indonesia, intensitas tweet hampir sama dengan kementerian kesehatan seperti di bawah ini : 


\section{Gambar10}

\section{Informasi Per-Minggu Badan Nasional Penanggulangan Bencana (BNPB)}

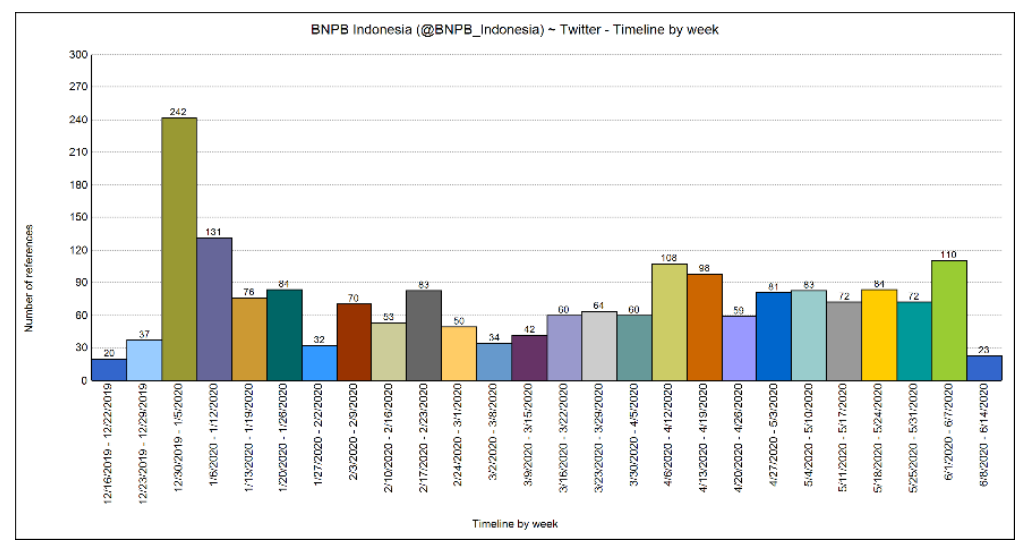

Pada gambar di atas dijelaskan aktivitas tweet yang dilakukan oleh Badan Nasional Penanggulangan Bencana Republik Indonesia, pada minggu pertama bulan Maret tanggal 1 Maret hingga 8 Maret 2020 jumlah postingan kemenkes 34 tweet. Pada minggu kedua bulan Maret jumlah postingan Kemenkes 42 tweet, pada minggu ketiga bulan Maret jumlah postingan Kemenkes 60 tweet, pada minggu empat bulan Maret jumlah postingan Kemenkes 64 tweet, pada minggu kelima bulan Maret jumlah postingan Kemenkes 60 tweet, pada minggu pertama bulan April 2020 jumlah postingan Kemenkes 108 tweet. pada minggu kedua bulan April jumlah postingan Kemenkes 98 tweet, pada minggu ketiga bulan April jumlah postingan Kemenkes 59 tweet, pada minggu empat bulan April jumlah postingan Kemenkes 81 tweet, memasuki minggu pertama bulan Mei 2020 jumlah postingan 83 tweet, minggu ketiga bulan Mei 2020 jumlah postingan 72 tweet, minggu empat bulan Mei 2020 jumlah postingan 84 tweet dan minggu lima bulan Mei 2020 jumlah postingan 72 tweet. Aktivitas tweet yang dilakukan oleh BNPB bukan hanya membahas covid-19 tetapi juga membahas terkait dengan bencana yang terjadi di Indonesia baik banjir, longsor dll. Dari data di atas tweet BNPB yang membahasan khusus tentang covid dengan pencarian \#covid sebanyak 1041 tweet. Ketepatan dalam penyampaikan informasi kepada masyarakat melalui twitter Kemenkes atau BNPB sangatlah penting bagaimana singkronisasi antara sosial media pemerintah satu dengan yang lainnya harus berkesinambungan dan memberikan informasi yang 
sama dan lebih baik saling mendukung satu sama lain dengan berbagai sisi pandangan. Dari tweet yang dilakukan oleh BNPB selama bulan Maret sampai akhir Juni ada 12 kali menyebutkan akun@kemenkesRI hal ini menunjukan masih sedikitnya berbagi informasi antara BNPB dan Kemenkes.

\section{KESIMPULAN}

Pola interaksi yang signifikan dalam media sosial platform twitter Kementerian Kesehatan Republik Indonesia dan Badan Nasional Penanggulangan Bencana pada saat pandemi covid-19 berdasarkan dengan arahan dari Presiden Republik Indonesia yang selalu memberikan informasi berlandaskan data-data yang akurat. Interaksi yang dilakukan oleh Kementerian Kesehatan Republik Indonesia pada saat pandemi covid-19 masuk ke Indonesia bulan Maret tahun 2020 sebesar 17.01\%, pada bulan April sebesar 17.33\%, dan pada bulan Mei sebesar 15.37\% yang berisi informasi terkait dengan protokol kesehatan jika mengalami gejala covid-19, situasi terkini perkembangan covid-19 di Indonesia, memberikan informasi terkait pasien covid-19, serta ajakan kepada masyarakat untuk tetap berada di rumah untuk memutus rantai penularan dan penyebaran covid-19.

Kementerian Kesehatan Republik Indonesia telah melakukan segala aktivitas berdasarkan himbauan untuk mengajak masyarakat agar tetap waspada pada covid-19. Akan tetapi usaha interaksi di platform twitter tidak menurun seiring dengan semakin melonjaknya covid-19. Interaksi twitter Badan Nasional Penanggulangan Bencana Republik Indonesia diawal masa pandemi yaitu pada bulan Maret tahun 2020 mempunyai nilai interaksi tweet sebesar 11.36\%, dibulan

April sebesar $18.72 \%$, dan ada bulan Mei sebesar $17.69 \%$ yang memberikan informasi terkait dengan pandemi covid-19, berbagai aspek di situasi pandemi seperti penanggulangan, pencegahan, hingga informasi terkonfirmasinya covid-19 di Indonesia.

Pola interaksi berdasarkan mentions sangat mempengaruhi jalannya aktivitas informasi di media sosial berbagai platform, ini dikarenakan saling mendukung serta menguatkan isi dari sebuah informasi dan relasi hubungan antara lembaga yang ada di suatu negara dengan beberapa tema yang sama. Pada platform 
twitter mentions sangat berguna untuk mendukung sebuah informasi dengan tema yang sama dan relevan akan dibahas lebih lanjut. Interaksi berdasarkan mentions pada akun twitter Kementerian Kesehatan Republik Indonesia dan Badan Nasional Penanggulangan Bencana Republik Indonesia saling berhubungan dengan beberapa akun twitter lainnya serta menunjukkan seberapa besar nilai interaksi yang dilakukan untuk mendukung penanggulangan pandemi covid-19.

Interaksi akun twitter Kementerian Kesehatan Republik Indonesia dan Badan Nasional Penanggulangan Bencana Republik Indonesia (BNPB) berdasarkan kosa kata yang sering disebutkan dalam membahas wabah corona virus (covid-19) pada bulan Maret, April hingga Mei tahun 2020 menyatakan bahwa ada beberapa kalimat yang sering disebutkan oleh KemenkesRI sebagai himbauan serta untuk memberikan motivasi kepada masyarakat Indonesia yaitu seperti rilissehat, healthies, kesehatan, bersama. Dalam hal ini Kemenkes masih mengajak atau memberikan motivasi untuk berkerjasama dalam menangani pandemi covid-19. Dalam akun tweet BNPB menyatakan bahwa kalimat yang sering digunakan yaitu covid, Indonesia, penanganan. Dalam hal ini jelas bagaimana BNPB memberikan ajakan dalam memerangi pandemic covid-19 dengan kalimat \#bersatumelawancovid19, dengan situasi saat ini akun twitter Kemenkes RI serta Badan Nasional Penanggulangan Bencana (BNPB) sama-sama mempunyai kalimat ajakan kepada masyarakat Indonesia dengan \#bersatumelawancovid19.

Komunikasi akun twitter@kemenkesRI dan@BNPB_Indonesia terhadap kebutuhan informasi pada masa pandemi covid-19 sangatlah penting di mana hal ini sangatlah penting komunikan yakin akan mengalami kepuasan, mengalami reaksi yang menyenangkan, memperoleh reward (balasan positif) dan terhindar dari punishment (keadaan, kondisi yang tidak enak) dari komunikator, jika menerima atau menggunakan isi pesannya. Informasi yang diberikan Kemenkes RI melalui tweet-nya adalah melaporkan kepada masyarakat jumlah pasien penderita covid 19 setiap harinya. Baik yang terkonfirmasi covid, negatif, positif ataupun yang meninggal, hal ini dilakukan oleh Kemenkes untuk memberikan data yang valid kepada masyarakat agar tidak bingung dengan berapa pasien yang terkonfirmasi covid-19. Pemerintah juga memberikan himbauan kepada masyarakat terkait 
dengan pencegahan dan penanganan penyebaran covid-19 di Indonesia. BNPB bukan hanya membahas covid-19 tetapi juga membahas terkait dengan bencana yang terjadi di Indonesia baik banjir, longsor dll.

Ketepatan dalam penyampaikan informasi kepada masyarakat melalui twitter k Kemenkes atau BNPB sangatlah penting bagaimana singkronisasi antara sosial media pemerintah satu dengan yang lainnya harus berkesinambungan dan memberikan informasi yang sama dan lebih baik saling mendukung satu sama lain dengan berbagai sisi pandangan.

\section{DAFTAR PUSTAKA}

Flo, E. (2020). MPR Soroti Perbedaan Data Korban COVID-19 antara BNPB dan Kemenkes. Retrieved from merahputih.com website:

https://merahputih.com/post/read/mpr-soroti-perbedaan-data-korban-covid-19antara-bnpb-dan-kemenkes

Munandar, H., \& Suherman, M. (2016). Aktivitas Komunikasi Pemerintahan Ridwan Kamil di Media Sosial. Prosiding Hubungan Masyarakat, 2(1).

Setiadi, A. (n.d.). Peanfaatan Media Sosial untuk Efektifitas Komunikasi. (1).

Susanto, E. H. (2017). Media Sosial Sebagai Pendukung Jaringan Komunikasi Politik. Jurnal ASPIKOM, 3(3), 379-398.

Widhana, D. H. (2020). BNPB: Data Corona Kemenkes Tertutup \& Tak Sinkron dengan Pemda. Retrieved from tirto.id website: https://tirto.id/bnpb-datacorona-kemenkes-tertutup-tak-sinkron-dengan-pemda-eLh2 